University of California, Hastings College of the Law UC Hastings Scholarship Repository

Faculty Scholarship

1990

\title{
Culture and Certainty: Legal History and the Reconstructive Project
}

Joan C. Williams

UC Hastings College of the Law, williams@uchastings.edu

Follow this and additional works at: http://repository.uchastings.edu/faculty_scholarship

Part of the Legal History Commons

\section{Recommended Citation}

Joan C. Williams, Culture and Certainty: Legal History and the Reconstructive Project, 76 Va. L. Rev. 713 (1990).

Available at: http://repository.uchastings.edu/faculty_scholarship/831

This Article is brought to you for free and open access by UC Hastings Scholarship Repository. It has been accepted for inclusion in Faculty Scholarship

by an authorized administrator of UC Hastings Scholarship Repository. For more information, please contact marcusc@uchastings.edu. 


\section{Faculty Publications \\ UC Hastings College of the Law Library}

Author: Joan C. Williams

Source: Virginia Law Review

Citation: 76 Va. L. Rev. 713 (1990).

Title: $\quad$ Culture and Certainty: Legal History and the Reconstructive Project

Originally published in VIRGINIA LAW REVIEW. This article is reprinted with permission from VIRGINIA LAW REVIEW and University of Virginia School of Law. 


\title{
CULTURE AND CERTAINTY: LEGAL HISTORY AND THE RECONSTRUCTIVE PROJECT
}

\author{
Joan C. Williams*
}

Forget this transcendent certainty, which is connected with your concept of spirit. . . Certainty is as it were a tone of voice in which one declares how things are, but one does not infer from the tone of voice that one is justified.

Ludwig Wittgenstem, On Certainty ${ }^{1}$

Culture is a deeply compronrised idea I cannot yet do without.

James Clifford, The Predicament of Culture ${ }^{2}$

DEOPLE like their conclusions to sound inevitable. A defining characteristic of the Western tradition is that argumentation follows from first principles through deductive logic to objective truth. A traditional argument begins with a highly abstract principle-for example, that human life is sacred. Then, as one's opponents are lulled into agreement, the argument takes unexpected turns: fetuses are babies, babies are human, and abortion is murder. . . . The traditional argument proceeds through logic to certainty.

A defining strategy of inodernism ${ }^{3}$ is to challenge this argumenta-

* Professor of Law, Washington College of Law, American University. B.A. 1974, Yale University; J.D. 1980, Harvard Law School; M.C.P. 1980, Massachusetts Institute of Technology. This work was generously supported by the American University-Washington College of Law Research Fund. I would like to thank Daniel R. Ernst, Hendrik Hartog, and Martha Minow for their extensive conments, which immeasurably inproved the piece. For additional help and guidance, thanks to Gregory S. Alexander, James X. Deinpsey, Mark M. Hager, David Lyons, James May, Dorothy Ross, Steven H. Schiffren, and the Cornell Law School Faculty Workshop. Special thanks to Rachel Wilkiams Deinpsey, and to William T. Fisher and the Harvard Law School Program on Legal History, where this paper was initially presented. Tom Grasso and Daphne Srinivasan gave expert research assistance. Mistakes that remain are inine alone.

1 L. Wittgenstein, On Certainty 8,6 (G. Anscombe \& G. von Wright eds. 1969) (enuphasis in original).

2 J. Clifford, The Predicament of Culture 10 (1988).

3 Modernisn, like liberalisın, means different things to different people. Here I use it to refer to what I have elsewhere called "new epistenology." See Williams, Critical Legal Studies: The Death of Transcendence and the Rise of the New Langdells, 62 N.Y.U. L. Rev. 429, 431-32 (1987). 
tive style. Since Nietzsche, assaults on truth have pursued a different style of justification. This Essay examines two modernist approaches, critiquing one (which I will call traditionalist) and advocating another (which I will call pragmatist). Both approaches begin with the argument that, though no absolute truths exist, this does not preclude the existence of particular truths. ${ }^{4}$ From here the two approaches diverge. Traditionalists abandon absolutes but seek to preserve ready access to certainty. They do so by arguing that, even without absolutes, our certainties remain quite certain, and our agreements, within a given culture, remain relatively objective. Pragmatism also holds out some hope of certainty, but it is certainty in the sense of knowing what are the moves within a particular language gaine, all the while recogmizing that the governing rules are subject to endless variation and adjustment.

For at least a decade legal historians have sought to define their relationship with modernism. Attention to this issue has been fitful, to be sure, in part because of the objectivist ethic deeply embedded im American history; ${ }^{5}$ most legal historians appear to go about their business of interpreting the past undisturbed by theoretical questions. ${ }^{6}$ A few legal historians have proven to be notable exceptions. ${ }^{7}$ Robert Gordon has argued that a conscientious embrace of modernism would change both the style and the subject matter of legal history. ${ }^{8}$ I agree that attention to theory could bring sweeping change to legal history, but I differ with Gordon on the content of the change.

In Part I, I argue that Gordon's structuralist analysis is fundamentally incompatible with historiographical nornis and for that reason is himited as a template for melding legal history with modernisin. In Part II, I examine alternative ways of melding legal history with mod-

4 A key divergence between pragmatism and post-structuralism is that pragmatists focus on the fact that particular (or partial) truths are truths, while post-structuralists focus on the fact that they are partial. See Harlan, AHR Forum-Reply to David Hollinger, 94 Am. Hist. Rev. 622, 625 (1989). See generally R. Rorty, Contingency, Irony, and Sohdarity (1989) (leading pragmatist's exploration of particular truths).

5 See generally P. Novick, That Noble Dream: The "Objectivity Question" and the American Historical Profession (1988).

6 Theoreticians often have aceused working historians of "theoretical torpor." See, e.g., H. White, Metahistory: The Historical Inagination in Nineteenth-Century Europe xii (1973).

7 Notable for methodological sophistication are those advocating "legal histories from the ground up." See infra note 133 and accompanying text.

8 Gordon, Critical Legal Histories, 36 Stan. L. Rev. 57 (1984). 
ernism. I discuss the work of two influential legal historians, both of whom adopt a traditionahist approach, and use their articles as a springboard for a general critique of traditionalism. This critique proceeds from the pragmatist perspective advocated in Part III, ${ }^{9}$ which explores how legal history can be melded with modernism by blurring the genres of legal, social, and imtellectual history and political theory. ${ }^{10}$ I call for an alliance of scholars to focus on what could be called the reconstructive project: ${ }^{11}$ rethinking justification $\mathrm{m}$ a world without absolutes. I conclude by suggesting that the study of legal doctrine holds special potential as a means of isolating the differences between traditional certainties and the situated certainties characteristic of modernism.

\section{LEgAL HISTORY AND MODERNISM: THE LIMITATIONS OF STRUCTURALIST HISTORY}

In the last decade, Robert Gordon has published two influential articles exploring the imphications of modernism for legal studies. ${ }^{12}$ In Critical Legal Histories, ${ }^{13}$ Gordon argues that we could explore modernist concerns through a new approach to the historical study of doctrine. "What could conceivably be radical-or, as some unkindly ask, even interesting-about rewriting the history of doctrine?" Gordon begins. ${ }^{14}$ His persistent use of a straw man, simultaneously bored and outraged by a focus on doctrine, highlights why the study of doctrine seems a methodologically radical move. The return to doctrine is a betrayal of the truths of the fathers, of the generation that the Wisconsin school dehivered from the dowdy backwaters of "lawyers' legal history."

9 For a discussion of what I mean by "pragmatism," see infra text accompanying notes 97 103.

10 C. Geertz, The Interpretation of Cultures 19 (1973).

11 Habermas uses the term "reconstructive sciences," but he means something very different. See T. McCarthy, The Critical Theory of Jürgen Habermas 276-79 (1988).

12 Gordon, Historicism in Legal Scholarship, 90 Yale L.J. 1017, 1017 (1981) (defining "historicism" as "the recognition of the historical and cultural contingency of law"); Gordon, supra note 8.

13 Gordon, supra note 8.

14 Id. at 57.

15 The term is William Nelson's, though I am using it somewhat differently than he does. See W. Nelson \& J. Reid, The Literature of American Legal History 235 (1985); see also Friedman, American Legal History-Past and Present, 34 J. Legal Educ. 563, 565-67 (1984) (comparing the approaches of the Wisconsin school and the "Critical school"). 
The core of Gordon's challenge to the Wisconsin school is his brilhant, sustained critique of functionalism, which (as he notes) had long smce lost respectability in the social sciences. The analysis of law as fulfilling societal needs, Gordon points out, sets up a dichotoiny between law and society that fails to recognize the extent to which law is constitutive of social relations. In place of "the comfort of traditional functionahist explanations," Gordon proposes "to treat legal forms as ideologies and rituals whose 'effects'-effects that include people's ways of sorting out social experience, giving it meaning, grading it as natural, just, and necessary or as contrived, unjust and subject to alteration - are in the realm of consciousness." 16 Gordon's calls to "relativize our own consciousness" and "to reconstruct as faithfully as possible the different inentalities of past societies"17 are reininiscent of abiding inodermist themes.

Gordon focuses on the "intellectual-history-of-doctrmal-contradictions approach"18 to legal doctrine that stems from Duncan Kennedy's apphication of structuralisin to the analysis of legal doctrine. The histories that follow Kennedy's inethodology start from the premise that our legal rules are indeterminate because they derive froin structures of thought that are fundamentally contradictory. To quote Gordon:

We are, the theory goes, constantly torn between our need for others and our fear of them, and law is one of the cultural devices we invent in order to establish terms upon which we can fuse with others without their crushing our identities, our freedoin, even our hives. ${ }^{19}$

Structuralist legal histories trace successive attempts to mask the fundamental contradiction. Because it "has never been (perhaps can never be?) overcome," Gordon notes, these "legal structures represent unsuccessful and thus inherently unstable inediations of that contradiction," destined "to becoine unglued and to collapse."20

16 Gordon, supra note 8, at 101.

17 Id.

18 Id. at 116 n.127. Gordon also discusses an alternative approach, the "history-from-thebottom-up account of oppressed groups struggling against ruling class versions of law and for their own versions." Id. at 117 . This is the approach adopted by the "legal histories from the ground up." See infra text accompanying note 133.

19 Gordon, supra note 8 , at 114 .

20 Id. Though, as Gordon notes, Blackstone's Commentaries "founded an entire school," id. at 115 , m my view Gordon lumps together a series of studies that are methodologically diverse. To the extent that the studies Gordon mentions sharply limit their time scope and 
While I agree with Gordon that modernism has important implications for legal history, structuralist legal histories have substantial drawbacks. Elsewhere I have argued that some influential structuralist histories, by contradicting their working assumption against privileged interpretations, fail to follow through the premises of modernism. ${ }^{21}$ Here I argue that Gordon's structuralist history has had little influence on professional historians because its reductiomst tendencies are inconsistent with historiographical nornis.

A basic tenet of historicism is that "[t]he meaning of history does not he hidden in some universal structure . . . but in the multiphicity of individual manifestations at different ages and in different cultures."'22 A well-known article on historicism notes: "Instead of trying to constrain reality within a system, we have dismissed the 'empty figment of one linear history' and learnt appreciation of the subtle shades of individuality, respect for irreducible particularity, acceptance of the untold 'multitude of facts'. . .."23

In intellectual history, historians' traditional commitinent to irreducible variety, to less sweeping, perhaps more conscientious descriptions, has transmuted into a hostility to linear narratives of ideal types. This shift reflects the modernist distrust of the "deinands of a typifying science." 24 Instead of looking for common elements, recent intellectual historians have preferred to build up a picture of an intellectual movement through thick descriptions, froin which intellectual currents emerge as a coinplex of overlapping tendencies, arguments, and outlooks. ${ }^{25}$

avoid reductionisn1, they can (and do) avoid the pitfalls of the structuralist history I critique. See infra note 40 .

21 See Williams, supra note 3, at 474-77.

22 Meyerhoff, Introduction to The Philosophy of History in Our Time 10 (H. Meyerhoff ed. 1959) [hereniafter Philosophy of History].

${ }^{23}$ Barraclough, The Historian in a Changing World, in Philosophy of History, supra note 22, at 30. See also Lee \& Beck, The Meaning of "Historicism," 59 Am. Hist. Rev. 568 (1954) (detailed examination of the term "historicisin").

24 Clifford, On Ethnographic Allegory, in Writing Culture: The Poetics and Politics of Ethnography 105 (J. Clifford \& G. Marcus eds. 1986) [hereinafter Writimg Culture].

25 The term "thick description" is, of course, froin C. Geertz, supra note 10, at 3. Important recent examinations of the niethodology of intellectual history include AHR Foruni: The Old History and the New, 94 Am. Hist. Rev. 654 (1989) [hereinafter AHR Forum]; Harlan, AHR Forum: Intellectual History and the Return of Literature, 94 Am. Hist. Rev. 581 (1989); Toews, Intellectual History After the Linguistic Turn: The Autonomy of Meaning and the Irreducibility of Experience, 92 Am. Hist. Rev. 886 (1987). 
A notable example is James Kloppenberg's recent article on liberalism. Because it highlights the limitations of structuralist legal history, I will discuss Kloppenberg's article in soine deptli.

Kloppenberg applies "a hermeneutic approaclı" to develop a readmg of liberalism that recovers the ethical dimension of liberal ideas and that highlights the difference between the liberalism of late eigliteentli-century political culture and "tlie flattened discourse of nineteenth-century individualism and democracy." ${ }^{26} \mathrm{He}$ does so by tracing three different traditions of colomial American ideas about virtue: religious, republican, and liberal. He proceeds not by constructing ideal types, but by illustrating how each tradition "was sufficiently extensive to contam contradictory ideas."27 He depicts each tradition not as a neat core of defining primciples, but as an overlapping series of related assumptions that at times serves more to focus points of conflict than to mandate agreement. Kloppenberg explicitly rejects the view that the stram of liberal thouglit that eventually turned into possessive individualism lias an abiding core stretching back to Thomas Hobbes. "That liberalism failed to make rapid progress either in England or in America precisely because, in Appleby's words, it 'rested upon a moral base so shallow as to threaten the whole complex of conventional religious precepts." "28 Kloppenberg instead lighlights the ethical dimension in the thought of liberal thinkers, noting that "a gap separated tlie intentions of liberal thinkers from the world of possessive individualism tliat eventually emerged." 29 He concludes:

Thus the ideas that sailed to America during the seventeenth and eighteenth centuries were rich in diversity and in ambiguity. ... Not only were [the three] conceptions of virtue not clearly compatible... [but] there were inconsistencies within each of the three traditions as well .... Each was unsteady enough by itself, but when combined

26 Kloppenberg, The Virtues of Liberalism: Christianity, Republicanism and Ethics in Early American Political Discourse, 74 J. Am. Hist. 9 (1987) [hereinafter Kloppenberg, The Virtues of Liberalism]. Kloppenberg has played a central role in intellectual historians' exploration of the implications of modernisin for intellectual listory. See, e.g., Kloppenberg, Deconstruction and Herneneutic Strategies for Intellectual History, 9 Intell. Hist. Newsl. 3 (1987).

27 Kloppenberg, The Virtues of Liberalism, supra note 26, at 13.

28 Id. at 15 (emphasis added).

29 Id. at 19. 
they became unpredictably explosive. ${ }^{30}$

Reviewing the range of hberal ideas in the American context, Kloppenberg stresses variation among regions and individuals.

Kloppenberg's analysis raises serious questions about structuralist histories' image of hiberalisin. Structuralist histories' bi-polar, good/ evil scenario is reminiscent of Progressive history - except that it sets up Liberalism, instead of Big Busimess, as the villam. Structuralist histories' vivid imagery of hberalism destroying the alternative feudal vision, stamping out governmental bodies other than the imdividual and the state, ${ }^{31}$ quashing repubhicanisin's vision of a community coinmitted to civic virtue, ${ }^{32}$ 1nasking in context after context the fundainental contradiction between our need for and fear of others, ${ }^{33}$ depends on a hberalisin eerily unified and unclianging over time, denuded of any ethical dimension or indeed of any ability at all to see beyond the virtues of self-interest.

If structurahist histories' insistence on a monolithic liberalisin is fundamentally inconsistent witl the atteinpt "to reconstruct ideas as they were thought," why did this plot have such persistent influence within legal scholarship? ${ }^{34}$ A clue emerges if one examines the oppo-

\section{Id.}

31 See Frug, The City as a Legal Concept, 93 Harv. L. Rev. 1059, 1149 (1980) (lamenting the cities' deeline of power and urging that they play an important role as "an alternative form of decentralized power in our society").

32 The hiterature on republicanisin is enormous, and in nost of the historical work the theine $I$ have identified is developed in a subtle and responsible way. As the republicanisin literature inoves out of history into legal and political theory, one hopes that conscientiousness will survive. Other commentators also have expressed apprelieusion. See, e.g., Hartog, Inposing Constitutional Traditions, 29 W1n. \& Mary L. Rev. 75 (1987) (questioning the traditional cliaracterization of constitutional history as a struggle between liberal and republican pohtical theories); Kerber, Making Republicanism Useful, 97 Yale L.J. 1663, 167072 (1988) (discussing the insights available through the political analysis of republicanism, but cautioning against an ahistorical interpretation of republicanism); White, The Studied Ambiguity of Horwitz's Legal History, 29 Wm. \& Mary L. Rev. 101, 110-12 (1987) (analyzing Horwitz's use of the listorical debate between liberalism and republicanism as a means to illuminate the present); G. Alexander, "Fragmented Survival": Republicanism as Rhetoric (Oct. 8, 1988) (unpublished paper delivered at the 1988 Conference on Critical Legal Studies, American Umiversity).

33 See, e.g., Kennedy, The Structure of Blackstone's Commentaries, 28 Buffalo L. Rev. 205 (1979) (discussing the theine of our dependence on and concurrent independenee froin others in the framework of Blackstone's Commentaries).

34 Kloppenberg, The Virtues of Liberalism, supra note 26, at 11. I argue below that structuralist history in fact lias liad limited infiuence among professional historians. See infra text accoinpanying note 40 . 
site of liberalism: a tightly focused desire for community and communion. This yearning for communion has been expressed in different ways, fron 1 Duncan Kennedy's psychological analysis of a desire for fusion, ${ }^{35}$ to Frug's advocacy of participatory democracy, ${ }^{36}$ to the neorepublicans' desire for a citizenry committed to civic virtue; ${ }^{37}$ but in each case the core motivation is a need to dramatize an alternative to America's contemporary version of possessive nidividualism. As a result, the histories all carry the same message: we need to identify how conteniporary ideology makes it hard for us to envision a civic good that goes beyond our society of shopping nialls.

This is not nonsense, but it is not history. It is the use of historical materials as fodder to articulate current and pressing concerns. In a sense, it is the hiberal/radical expression of the pervasive sense that soniething has gone wrong in this society, something related to the eighties' celebration of materialisn 1 and self-interest. ${ }^{38}$

Of course, one imphication of nodernisn is that all histories are either presentist or bornig. Given that every interpretation reflects a particular viewpoint, historical interpretations that resonate do so because they speak to current concerns. ${ }^{39}$ But there is good presentisn 1 and bad, or, to state the distinction n1ore accurately, at some point the discussion cares so much about the present that it ceases to concern itself with a conscientious respect for the pastness of the past. At the extreme end of this insensitivity to incommensurability is not nonsense, but neither is it history.

Professional historians have "voted with their feet," so to speak, in response to Gordon's manifesto. Despite structuralist legal history's considerable influence within Critical Legal Studies (CLS), it has had relatively little inipact among professional historians. ${ }^{40}$ The renrain-

\footnotetext{
35 See Kennedy, supra note 33, at 211-12.

36 See Frug, supra note 31.

37 Cf. Kerber, supra note 32, at 1671 (arguing that republicanism lacks the rlietoric of equal access to participation and deliberation that many modern scholars who advocate republicanism seek to preserve).

38 The New Right shares this sense of something gone awry, though in its view the problem is caused by an abandonment of traditional values.

39 This point has been made among imtellectual historians, but arguably is less widely influential among social and legal historians. See, e.g., Harlan, supra note 25.

40 I want to make clear that I am arguing against the reductionism characteristic of many structuralist legal histories published in law reviews, not against their underlying project: to explore the history of legal ideology as expressed in legal doctrines. An outstanding example of nonreductionist structurahist history is Gregory Alexander's study of the development of the
} 
der of this Essay delineates a new way of melding legal history with modernism, one that involves a blurring of the genres of legal, social, and intellectual history and pohtical philosophy. My call is for an alliance of scholars whose goal is to rethink justification in a world without absolutes. Legal historians, I argue im the following two sections, can play an important role in exploring the implications of both the traditionalist and the pragmatic approaches to the reconstructive project.

\section{Traditionalism: The Persistence of Certainty Talk IN THE AGE OF INTERPRETATION}

[T]raditionalism seeks to recover as much of what the transparency thesis would otherwise yield - given the loss of transparency itself by reference and appeal to the inherent cognitive directionality of the historical traditions in which humans are forever einbedded.

Joseph Margolis, Pragmatism Without Foundations ${ }^{41}$

Two prominent historians already have joined the reconstructive project. William Nelson in "History and Neutrality in Constitutional

law of trusts, which interprets trust law as an integral part of the flowering of nineteenthcentury hiberal ideology. Alexander, The Transfornation of Trusts as a Legal Category 18001914, 5 Law \& Hist. Rev. 303 (1987). Alexander carries on the project of structuralist history, but without the insistent reductionism of the fundamental contradiction or the sweep of an eternal liberalisn. In effect, he uses legal doctrine to study in detail how the ideology of the elite limits tlie scope of the thinkable. This approach acknowledges that a study of doctrine has limitations in that it nuarginalizes the legal consciousness of nonelite groups, but studies doctrine nonetheless to gain access to the social construction of knowledge by the elite. Though Alexander has shown the approach to be a fruitful one, the objection of the "historians from tle ground up" echoes: doesn't limiting the imquiry to doctrine silence some of the voices that offer the niost interesting and accessible alternatives to the hegemony we wish to escape, or at least reconsider? See infra text acconipanying note 133. Although this question echoes, it ultimately does not persuade. After all, doesn't the study of how elite ideology limited the scope of the thinkable simply involve a different focus than the study of how nonehite groups attenupted to widen the scope of possibilities?

41 J. Margohs, Pragınatism Without Foundations xviii (1986). By tlie "transparency thesis" Margolis refers to the view that the truth nerely mirrors an outside reality.

For a suggestive analysis of traditionalism within political theory, see S. Okin, Justice, Gender and the Family (1989). I strongly suspect Okin would disagree with iny cliaracterization of Rawls as a traditionalist. See infra text accompanying notes 53-60. The two thinkers she analyzes as traditionalist are Alasdair MacIntyre and Michael Sandel. See S. Okin, supra, at 41-73. 
Adjudication"42 and Thomas Haskell in "The Curious Persistence of Rights Talk in the 'Age of Interpretation" "43 both address the question of justification in a world without absolutes. Nelson asks if constitutional adjudication can be neutral without reference to truth; Haskell examines how to justify "rights talk" in a inodernist environment.

Both authors adopt a traditionalist position. That is, both argue that the legal language they examine is functionally neutral (Nelson's tern1) or objective (Haskell's) because it commands widespread agreement within American culture. Both by the questions they address, and by the answers they give, Haskell and Nelson develop arguments parallel to those of pohitical philosophers engaged in the reconstructive project, notably John Rawls. (The blurring of legal history and pohtical philosophy has already begun.)

Although traditionalism identifies some crucial issues within modernism, its initial assumption of a widespread consensus is fundamentally at variance with the iniage of American society developed during the last twenty years by the new social historians. The traditionalist position attracts historians nonetheless, I argue, because of historians' tendency to conceptualize past eras as coherent totalities incommensurate with their own. This characteristic methodology has hindered historians in their reassessment of the assumptions behind the traditional, hohstic concept of culture. I examine philosophical and anthropological hiterature to deconstruct the concept of culture and to explore the limitations of a traditionalist approach.

\section{A. Traditionalism Defended}

Both Haskell and Nelson frame their discussions in a rhetorical mode characteristic of traditionalism. Both express the fear that the modernist critique of absolutes could lead to a relativism that leaves us inorally adrift, "thinking pushpin as good as poetry, regarding Hitler as just a fellow with unstandard tastes" (Clifford Geertz'

42 Nelson, History and Neutrality in Constitutional Adjudication, 72 Va. L. Rev. 1237 (1986).

43 Haskell, The Curious Persistence of Rights Talk in the "Age of Interpretation," $74 \mathrm{~J}$. Am. Hist. 984 (1987). It is perhaps significant that Haskell, whose approach is the more sophisticated of the two authors I discuss, is not strictly a legal historian. He is an intellectual historian who has played an integral part in the debate over the implications of inodernism for intellectual history. See supra notes 26,39 , and accompanying text. 
words, not theirs). ${ }^{44}$ Nelson names this threatening possibility "irrationalism" and attributes it to CLS. Haskell calls it Nietzschean, and builds his text around the need to provide Amnesty International with a firm moral foundation for principled objections to torture. Against this somewhat alarmist background Haskell argues that what is needed is an argument that is not only strong but compelling: a rehiable, objective defense against Nietzsche's conclusion that after the death of transcendence only the will to power remains. Haskell clearly is appalled by Nietzsche's invitation to move "beyond good and evil."

Haskell aptly captured traditionalism's allure: it allows adherents to argue that traditional universals-albeit mere conventions-retain their traditional status as "objective" truths within a culture. Thus, traditionalists can provide the "safe haven" Haskell seeks for rationality and certainty while rejecting the absolutes that traditionally anchored them. The underlying message is that the critique of absolutes is no cause for alarm, because the new, social certainties differ hittle from the old, transcendental ones.

Nelson has a similar project. He sets out to defend the view that judges can decide constitutional cases by reference to neutral principles, so he agrees with Haskell on the need for firm, objective answers; yet neither scholar attributes objective, neutral principles to eternal truths. Instead, both argue that objectivity stems from conventions held within a culture. These conventions achieve objectivity and universality because to share a culture is to share consensus.

Nelson states this culture-as-consensus argument with few qualifications. Accordinig to

the method of neutral principles adjudication ..., even though American society is characterized by deep cleavages and conflicting social practices, nearly all Americans accept and participate in an abiding social consensus. This consensus binds society together, and if it did not exist, society itself could not exist. The consensus manifests itself im law, im ideologies, and im social practices to which most Americans proclaim adherence and from which all but the most extreme social

44 Geertz, Distinguished Lecture: Anti Anti-Relativism, 86 Am. Anthro. 263, 264 (1984). Within legal scholarship, the fear of relativisın drives the charge of "nihilism." See Fish, Fish v. Fiss, 36 Stan. L. Rev. 1325 (1984); Fiss, Objectivity and Interpretation, 34 Stan. L. Rev. 739 (1982); Williams, supra note 3 , at $470-71$. 
and political dissidents derive personal benefit. ${ }^{45}$

Underlying this statement are several assumptions. Nelson begins by assuming that to share a culture is to share a consensus; yet in the next breath he acknowledges that his "consensus" in fact is not shared by everyone within American society. Nonetheless, in his view, decisions based on the consensus are "neutral." Nelson does not explain why the viewpoint of those who agree with the consensus is more important than the viewpoint of those who do not, though he intimates a reason: the only people outside the consensus, he implies, are "the most extreme social and political dissidents." 46 Nelson never (explicitly) argues that the majority's viewpoint is better. Its "objectivity" and "neutrality" appear to be simply a function of its predominance within society. Without wishing to seein disrespectful, I read this as the Nietzschean argument that, after the death of God, power is the ouly available justification.

Haskell's analysis is more subtle and requires a more nuanced response. He begins by arguing that ethics in general, and rights in particular, are mere "rational conventions," not eternal truths. But it quickly becomes clear that these rational conventions are firm indeed. "Rights need not be either eternal or umversal, but if they are to do us any good, they must be rooted deeply enough in the human condition to win the loyalty of more than a few generations (and ideally, more than a few cultures)." ${ }^{\prime 4}$ While Haskell is reluctant to make claims for cross-cultural umversals, he shares with Nelson a readiness to claim that "rights and other clains to objective moral knowledge can enjoy something like 'umiversal' sway" within a specific culture. ${ }^{48}$

45 Nelson, supra note 42, at 1269 (citation omitted).

46 Id.

47 Haskell, supra note 43, at 1004.

48 Id. at 1008. Haskell quotes the philosopher Steven Collins, who appears to make an ambitious conventionalist argument: "If we assume," says Collins,

that there is a set of basic predicaments which define what it is to be human, then they will neither vary cross-culturally nor develop historically. As to their origin, we may claim, with Durkheim, that in so far as some of them are inextricably linked with the existence of society (as, for instance, personhood) they may be said to arise from the empirical fact of society, but to be given in this way a priori to individuals. In so far as some predicaments may be at the mercy of a variety of non-umiversal, perhaps historical, factors, they may be said (i) to originate empirically, (ii) to vary crossculturally . . . and (iii) to develop historically. This lays out a spectrum of possibilities well suited to a conventionalist conception of rights. 
Both Haskell's wariness about cross-cultural universals and his confidence in universal moral mandates within a society presuinably grow out of his ongoing study of the shift to humanitarianisin in the eighteenth century. In this study Haskell examines why slavery was transformed around 1750 "from a problematical but readily defensible institution into a self-evidently evil and abominable one,"49 providing along the way a fascinating series of hypotheticals designed to highlight the conventional nature of moral verities. If he were to get im a plane today, Haskell notes, he could save someone in India from starving tolnorrow. That he does not is because that starving person is not defined within the ambit of his responsibility. Before 1750, slaves held a position similar to that of the starving Indian. Thereafter, because of changes associated with the rise of the market, slaves entered Europeans' anibit of responsibility. As a result, slavery began to be viewed as immoral.

Haskell's analysis is persuasive on the shift in European sensibility and on the view that ethics are a matter of convention. But on closer inspection he does subtly what Nelson does openly: he privileges the viewpoint of the majority, thereby excluding from view the existence of intra-societal disagreeinents. Unlike Nelson, whose language exphcitly states his intention to inarginalize as extremist dissidents those who do not share his "consensus," Haskell is more ainbivalent.

Collins, Categories, Concepts of Predicaments? Remarks on Mauss's Use of Philosophical Terminology, in The Category of the Person: Anthropology, Philosophy, History 70, 73 (M. Carrithers, S. Collins \& S. Lukes eds. 1985) quoted in Haskell, supra note 43, at 1004-05. The question is what would fall in the first category and what in the second. Collins' language implies to me (as well as to Haskell) that we should try mightily to keep important principles in the first category. Haskell is attracted to Collims' argument because it helps him defend "the existence of nonmetaphysical categories that are so deeply rooted in the hnman condition that they do not vary significantly between cultures or across time." Haskell, supra note 43, at 1004. Despite Collins' disclaimers, his vision is deeply traditional in that it searches for and finds a "permanent neutral framework" that "satisfies the . . . need to be gripped, grasped and compelled." R. Rorty, Philosophy and the Mirror of Nature 8, 161 (1979).

49 Haskell, Capitalism and the Origins of the Humanitarian Sensibility, Part 1, 90 Am. Hist. Rev. 339 (1985) [hereinafter Haskell, Capitalism I]; see also Haskell, Capitalism and the Origins of the Humanitarian Sensibility, Part 2, 90 Am. Hist. Rev. 547 (1985). Haskell's study is critiqued in an American History Review forum. See Ashworth, The Relationship Between Capitalism and Humanitariamisin, 92 Am. Hist. Rev. 813 (1987); Davis, Reflections on Abolitionism and Ideological Hegemony, 92 Am. Hist. Rev. 797 (1987). Haskell's response develops the themes of "Persistance of Rights Talk." Haskell, Convention and Hegeinonic Interest in the Debate over Antislavery: A Reply to Davis and Ashworth, $92 \mathrm{Am}$. Hist. Rev. 829 (1987). 
At times, he appears to argue against his own assumption of consensus. In "Persistence of Rights Talk," he defines rights as "a perpetual object of contention between rival groups with strong vested interests." So Similarly, in his study of the rise of humanitarianism, he refers to dissension within the ranks, noting that reformers such as Marx saw no distinction between chattel slavery and wage slavery. "The conventions I have in mind," he notes, "are always open to criticism froin the vantage point of rival conventions." 51 However, while Haskell occasionally glimpses the intense antagomism of rival certainties, it fails to shake his confidence in Rawls' claim that "inoral objectivity ... [can] be understood in terms of a suitably constructed social point of view that all can accept.' "52

Haskell's rehance on Rawls is telling. Rawls' work simce $A$ Theory of Justice abandons his original Kantian epistemology in favor of a culture-as-consensus approach. ${ }^{53}$ Rawls' argument contains anbiguities similar to those in Haskell's work. In some contexts, Rawls is sensitive to sharp disagreements; indeed, he frames his theory around the fact of post-reformation pluralism. ${ }^{54}$ A workable potitical theory, he notes, "must allow for . . . the plurality of conflicting, and indeed incommensurable, conceptions of the meaning, value and purpose of human life . . a affirmed by the citizens of democratic societies."ss At times Rawls seems to conclude that this situation may threaten the possibility of consensus on "shared institutions and basic

50 Haskell, supra note 43, at 1005 .

51 Haskell, Capitalism I, supra note 49, at 352.

52 Haskell, supra note 43, at 1008 (quoting Rawls).

53 For a discussion of Rawls' relationship to Kant, see Davidson, Is Rawls a Kantian?, 66 Pac. Phil. Q. 48 (1985); Hoffe, Is Rawls' Theory of Justice Really Kantian?, 26 Ratio 103 (1984). For an interesting analysis of Rawls' recent shift to a more historicist position, see Esquith \& Peterson, The Original Position as Social Practice, 16 Pol. Theory 300 (1988). Rawls has abandoned his Kantian perspective only in the sense that he does not claim that his principles, his truths-that-compel-agreement, reflect some underlying structure. Yet Rawls remains deeply traditional in his refusal to abandon the search for objective truths that coinpel agreement. Thus, from a praginatist perspective, Rawls remains committed to a conversational goal that shonld be abandoned.

54 See Rawls, Justice as Fairness: Political, Not Metaphysical, 14 Phil. \& Pub. Aff. 223 (1985).

55 Rawls, The Idea of an Overlapping Consensus, 7 Oxford J. Legal Stud. 1, 4 (1987) (citation omitted) [hereiuafter Rawls, Overlapping Consensus]; see Rawls, supra note 54, at 225-26, 245. 
arrangements":56

We do not, of course, assume that an overlapping consensus is always possible .... It is often obvious that it is not, not at least until firmly held beliefs change in fundamental ways. But the point of the idea ... is to show how, despite a diversity of doctrines, convergence on a pohitical conception of justice may be achieved and social unity sustained in long-run equilibrium, that is, over time from one generation to the next. ${ }^{57}$

Like Haskell, Rawls acknowledges disagreement; like Haskell, he preserves consensus at the center of his vision. "Our hope is that there is a common desire for agreement, as well as sufficient sharing of certain underlying notions and imphicitly held principles, so that the effort to reach an understanding has some foothold."58 Rawls continues:

The real task is to discover and formulate the deeper bases of agreeinent which one hopes are embedded in common sense, or even to originate and fashion starting points for common understanding by expressing in a new form the convictions found in the historical tradition by coimecting them with a wide range of people's considered convictions: those which stand up to critical reflection. ${ }^{59}$

In these passages Rawls preserves his conviction that consensus exists out there, if we can only find or fashion it, without retaining his original Kantian rationale for its existence. No underlying structures compel us to agree, Rawls seems to argue, we just do-or, inore accu-

56 Rawls, Kantian Constructivism in Moral Theory, 77 J. Phil. 515, 517 (1980) [hereinafter Rawls, Kantian Constructivism]; see Rawls, supra note 54, at 226-27; Rawls, Overlapping Consensus, supra note 55 , at 4 .

57 Rawls, Overlapping Consensus, supra note 55, at 5 (citation omitted).

58 Rawls, Kantian Constructivism, supra note 56, at 518. Rawls has used slightly different phrases to describe this. See Rawls, Overlapping Consensus, supra note 55, at 6 ("fundamental intuitive ideas viewed as latent in the public political culture"); Rawls, supra note 54, at 229 ("we must find a new way of organizing familiar ideas and principles into a conception of political justice so that the claims in conflict, as previously understood, are seen in another light").

59 Rawls, Kantian Constructivism, supra note 56, at 518. Rawls is ambiguous on whether the consensus lie hopes for needs to be fashioned or inerely found. In contexts where he focuses on disagreement, he appears to assuine that consensus inust be faslioned. See, e.g., Rawls, supra note 54, at 226 (if underlying basis of agreement cannot be uncovered, perhaps divergence of opimion can be narrowed sufficiently to ensure cooperation and mutual respect). In other contexts Rawls uses language that inakes his "consensus" sound inore found than fashioned. See, e.g., Rawls, Overlapping Consensus, supra note 55, at 24-25 (political philosoplyy "lopes to uncover, and to lielp to articulate, a shared basis of consensus"). 
rately, we just will if we correctly interpret our tradition. ${ }^{60}$

It is at this point that the role of historians emerges, for Rawls has inade not a philosophical but an historical claim. The most recent generation of historians has not found the consensus Rawls "hopes" is embedded in "imphicitly held principles." In fact, the new social history of the past twenty years has been dedicated largely to challenging the image of consensus projected by American historians of the fifties and sixties. ${ }^{61}$ "We [Americans] have debated fiercely," said Clinton Rossiter in 1962, "but as inen who agreed on fundamentals and could thus afford to sound more ferocious than we really were. We have all spoken the same political language; we have made the same political assumptions; we have all thought the same political thoughts."62 Authors disagreed about whether the consensus was fruitful or oppressive, but they shared the image of widespread agreement. ${ }^{63}$

Since then, social historians have explored America's lack of consensus. ${ }^{64}$ Said one commentator, Lawrence Veysey, in 1979:

Social historians emphatically reject the hohsm of the older intellectual historians and also the dualistic lines of conflict ... of the older pohitical historians. Instead the inhabitants of a given nation-state are seen to form an extraordinarily comphicated inosaic. ... Each element in the mosaic must therefore have an utterly separate history. And there is hittle incentive to try to piece these histories together into a whole ... because the parts are seen as the realities, the whole as an

60 My critique here concerns Rawls' methodology, not his substantive principles-though I would argue that it is not possible to keep the two clearly separate. See Nagel, "Rawls on Justice," in Reading Rawls 1, 3 (N. Daniels ed. 1974). Another crucial question concerus how Rawls expects to establish a (single) correct interpretation of our tradition. Sec H. Gadamer, Truth and Method 273-74, 337-41, 358-60 (1975).

61 For an early critique, see Higham, The Cult of the "American Consensus": Homogenizing Our History, 27 Commentary 93 (1959); see also Higham, Beyond Consensus: The Historian as Moral Critic, 67 Am. Hist. Rev. 609 (1962); A Round Table: What Has Changed and Not Clianged in American Historical Practice, 76 J. Am. Hist. 393 (1989) (symposiun issue) (including anotler article by Higham) [hereinafter JAH Round Table].

62 Quoted in D. Rodgers, Contested Truths 8 (1987).

63 See P. Novick, supra note 5, at 333-35.

64 See Levine, AHR Forum-The Unpredictable Past: Reflections on Recent American Historiography, 94 Am. Hist. Rev. 671 (1989) (reassessing the new social history). Levine's essay is part of an interesting recent reassessinent of this revisionism. See generally AHR Forum, supra note 25 . For other recent discussions of the relationship between consensus history and the new social history, see P. Novick, supra note 5, at 333-35, 439-40; JAH Round Table, supra note 61 . 
artificial construction ....65

Social historians have documented black, women's, and working-class subcultures, each of which harbors ways of being and understanding fundamentally at variance with the "consensus" heretofore assumed. A particularly pointed example is historians' exploration of the ideology of domesticity as an internal critique of capitahsm, or, in the words of Nancy Cott, "a cri de coeur against inodern work relations." Historians of the working class have also documented how those groups shared values and life patterns fundamentally at variance with those of white middle-class males. ${ }^{67}$

Intellectual historians as well have spent the last twenty years exploring the limitations of American consensus. They have replaced the Hartzian image of abiding consensus with a sustained and intensive inquiry into republicanisn 1 as an alternative tradition. ${ }^{68}$ Whether or not the diverse uses of republican rhetoric reflect a coherent repubhcan tradition, one with persistent force as a "dangerous supplement" to hiberahsm, the existence of a repubhican tradition is virtually undisputed. ${ }^{69}$ At a minimum, the hiterature on republicainsni illustrates the persistence of an alternative political rhetoric ${ }^{70}$ that social critics, workers, and other outgroups have used to ground a social critique promising a vision of comnunity lacking in the dominant liberal

65 Veysey, The "New" Social History in the Context of American Historical Writing, 7 Rev. Am. Hist. 1, 5 (1979).

66 N. Cott, The Bonds of Womanhood: "Woinan's Sphere" in New England, 1780-1835, at 70 (1977).

67 See, e.g., C. Stansell, City of Women (1986); S. Wilentz, Chants Democratic (1984). For a brief summary of recent labor history literature, see Fine, American Labor History in the 1980's: The Quest for Synthesis Continues, 17 Rev. Am. Hist. 259 (1989), and sources cited therein.

${ }^{68}$ The hiterature on republicanisin is enormous. For a reading of its current state, see Banning, Quid Transit? Paradigms and Process in the Transformation of Republican Ideas, 17 Rev. Am. Hist. 199 (1989), and sources cited therein.

69 See D. Rodgers, supra note 62 , at 9-10 (liberalism and republicanism not distinct, mutually exclusive world views); Banning, supra note 68 (noting general, though not unanimous, agreement that repubhcanism and liberalisın coexisted); Hartog, supra note 32 , at 75.

70 Current scholarship suggests that liberalism and republicanisin were never sharply defined alternative paradigms, but were always present, so to speak, in solution. (The metaphor is froin Dorothy Ross, Conversation with Dorothy Ross, Professor of History, University of Virginia (Dec. 15, 1989).) This refinement does not change the point made in the text: the challenge is to isolate different mixtures and apply thein successfully toward one's political and rhetorical goals. 
mode. ${ }^{71}$

More recently, intellectual historians reexamining liberalism liave fractured not only liberalism's consensus, but liberalism itself. Scliolars such as Joyce Appleby, Hendrik Hartog, and Jaines Kloppenberg have rediscovered the elements of liberahism at variance with the tradition of possessive individualisin that has predominated at least since the late nineteenth century, if not before. Kloppenberg has excavated the ethical dimension of early liberal thought; ${ }^{72}$ Hartog has led the movement, discussed below, which explored how the rhetoric of riglits has been captured by women, workers, and blacks; ${ }^{73}$ Appleby has studied the liberating impact of liberalism in its initial contexts. ${ }^{74}$

American historians have documented the pluralism of American society. In this context, the traditionalist assumption that sharing a culture means sharing a consensus becomes simply unconvincing. Though Haskell's and Nelson's assuinption of immanent social consensus seems strangely inconsistent with the anti-consensus interpretation predominant in both social and intellectual historiography, traditionalism may coine naturally to some historians because of the contextualist method characteristic of historicism. ${ }^{75}$ In historians' attempts to explain and preserve the pastness of the past, they tend to conceptualize past eras as coherent totalities imcommensurate witl their own.

Maurice Mandelbaum has argued that the shift from nature to culture was a key element of the development of historicism. ${ }^{76}$ In the eighteenth century, theorists tended to think of societies as collections of individuals who acted according to universal laws of human nature. Nineteenth-century scholars shifted attention to culture, and culture,

71 See, e.g., S. Wilentz, supra note 67 (workers); Kerber, supra note 32 (social critics); Oakes, From Republicanism to Liberalism, 37 Am. Q. 551 (1985) (republicanism in the Soutli).

72 Kloppenberg, The Virtues of Liberalism, supra note 26, at 9.

73 Thelan, Rights Consciousness in American History, 74 J. Am. Hist. 795, 797 (1987) (crediting Hartog). See infra notes 123-27 and accompanying text.

74 J. Appleby, Capitalisin and a New Social Order (1982).

75 This is not to deny the political choices implicit in the traditionalist positions of Nelson and Haskell. Note that the new social historians' challenge to the vision of widespread consensus was part of a very self-conscious "left" movement. See P. Novick, supra note 5, at 417-38; Berkhofer, Clio and the Culture Concept: Some Impressions of a Changing Relationship in American Historiograpliy, in The Idea of Culture in the Social Sciences $78 \mathrm{n} .1$ (L. Schneider \& C. Bonjean eds. 1973) [heremafter The Idea of Culture].

76 M. Mandelbaum, History, Man \& Reason 163-91 (1971). 
rather than nature, became the most often cited determinant of human behavior. Romantic scholars tended to stress the diversity of life forms, while Idealists tended to stress the coherence that bound these diverse manifestations imto the Spirit of an Age; yet both traditions retained an underlying conviction of colrerence within a form of life. ${ }^{77}$ This conviction leads easily to the traditionalist view that values, though mere conventions, remain "objective" within a given culture.

Once historians jom the reconstructive project, they will need to reexamine their assumptions privileging colrerence and agreement. For help in this task, historians can usefully turn to anthropological and philosophical literature; for, unlike historians, anthropologists and philosophers have not taken as unproblematic the traditional view of culture as consensus.

\section{B. Traditionalism Critiqued}

It is high time that cultural and social totalities are subjected to the kind of radical questioning that textual ensembles have undergone in recent critical practice....

James Clifford, The Predicament of Culture ${ }^{78}$

Imphicit in the traditionalism of Rawls, Haskell, and otlers is the classic view of culture as a coherent totality that determines behavior. While the culture concept lias received scholarly attention in a range of different fields, ${ }^{79}$ two literatures prove particularly lelpful in clari-

$77 \mathrm{H}$. White, supra note 6 , at 75-89.

78 J. Clifford, supra note 2, at 274. Dominick LaCapra has noted, and criticized, the central role the culture concept plays in current historical studies.

[T] he concept of "culture" is well on the way to becoming the totein for a consensus on the proper object and inethod of research in historiography. ... Yet the very proliferation of definitions is a sign of the impediments to consensus and the need for inquiry into the problems left unresolved by an almost oneiric rehance on the coucept of culture.

D. LaCapra, History \& Criticisin 72 (1985). Anthropologists other than Clifford have different (and often less critical) views of the culture concept. See generally The Relevance of Culture (M. Freilich ed. 1989) (reviewing different approaches to the culture concept within contemporary anthropology).

79 See generally The Idea of Culture, supra note 75 (exploring the implications of the culture concept for history, anthropology, sociology, political science, and other disciplines). For discussion of historians, see Berkhofer, supra note 75; Chartier, Intellectual History or Sociocultural History? The French Trajectories, in Modern European Intellectual History: Reappraisals and New Perspectives 13, 18-19 (D. LaCapra \& S. Kaplan eds. 1982). Berkhofer 
fying the limitations of the traditional holistic view of culture: the philosophical literature interpreting Wittgenstein's "forms of life" and the recent work of post-inodern anthropologists.

Wittgenstein acknowledged that his notion of totality was "very badly expressed, and probably badly thouglit as well." 80 Few others have been so candid, but the problem is a common one. ${ }^{81}$ Philosophers' discussions of Wittgenstein's forms of life provide a useful perspective on the image of culture as consensus that underlies the traditionahist position. The traditionalist interpretation of Wittgenstein's philosopliy stresses that, althougli Wittgenstein exhorts us to eschew "transcendent certainty," le inerely shifts the basis of certainty from transcendence to "forms of life," a phrase lie sometimes explicitly associates with the term "culture." 82 At its most extreine, the traditionalist interpretation implies that it is impossible to criticize a form of life from the inside, since to participate in a culture is to accept existing social certainties. ${ }^{83}$ Soine passages in Wittgenstein's writings appear to support this view, as, for example, wlien Wittgenstein associates certainty with "the inherited background agamst which I distinguish between true and false," and when lie speaks of "comfortable certamty" as a form of life, "soinething that lies beyond being justified or unjustified." 84

But what is a "comfortable certainty"? Keep in mind that Wittgenstein was a philosopher and largely limited himself to traditional philosophical topics. He desigued mucli of his discussion of certainty to suggest the absurdity of G.E. Moore's prolonged discussion about

has associated the culture concept with consensus history. New social historians, he has recently argued, turn away from culture to focus instead on society. See Berkhofer, Comment on "Social History as Lived and Written," 84 Am. Hist. Rev. 1326, 1326-27 (1984). As my text indicates, see infra text accompanying notes 104-111, I disagree. In my view, the new social historians did not abandon a search for "culture," they simply relocated it in subgroups.

${ }^{80} \mathrm{~L}$. Wittgenstein, supra note 1, If 358 (discussing "forms of life"). The construct inost often associated with Wittgenstein is that of "language games," but he himself noted that to understand a language is to understand a culture. L. Wittgenstein, Lectures and Conversations on Aesthetics, Psychology and Rehious Behef โी 25-26 (C. Barrett ed. 1966). See also G. Baker \& P. Hacker, Wittgenstein: Meaning and Understanding 136-37 (1983) (discussing forms of life). See generally Williams, supra note 3, at 450-54 (linking forms of life with culture concept).

81 For an insightful analysis of Fish's "interpretative commumities," see Schlag, Fish v.

Zapp: The Case of the Relatively Autonomous Self, 76 Geo. L.J. 37, 46-50 (1987).

82 See Wilhams, supra note 3 , at 452-53.

83 See Hinman, Can a Form of Life be Wrong?, 58 Philosophy 339 (1983).

84 L. Wittgenstein, supra note 1, Iโ 94, 357, 359 (emphasis in original). 
whether or not he in fact knew his hand was his hand. Surely, said Wittgenstein, that was a comfortable certainty. ${ }^{85}$ But Wittgenstein was careful to distinguish between comfortable certainties and "certainty that is still struggling." 86 His argument was addressed to philosophical skepticism, and his basic point was that an entire form of life could not be called into question simultaneously: "A doubt without an end is not even a doubt."87 Yet Wittgenstein did not design his analysis to support the view that every "certainty" within society reflects the kind of consensus that leads us to know that our hands are, indeed, our hands. In fact he exphicitly disclaims this view. "'So you are saying that human agreement decides what is true and what is false?' It is what human beings say that is true and false; and they agree in the language they use. That is not agreeinent in opimons but in forms of life." 88

We can only guess how Wittgenstein umght have drawn the line between opimions and forms of life. For now my point is that a traditionalist position fails to make this crucial distinction accurately. Traditionalists tend to assume that agreeinent about forms of life entails agreement about opimions. This is the view that underlies their vision of culture as consensus. Altlough philosophy can help thein delineate the distinction between opimions and forms of life, philosophers have not (to my knowledge) focused sustained attention on the assumptions underlying the view that culture provides a safe haven for objective moral and episteinological claims. Recent anthropologists liave done so in a body of work that lias important implications for the reconstructive project. Their target is the traditional concept of culture given its classic form in E.B. Tylor's "sharp and successful conceptualization" of 1871: "Culture or Civilization, taken in its wide ethnographic sense, is that complex whole which includes knowledge, behief, art, morals, law, custom, and any other capabilities and liabits acquired by man as a nember of society." 89 This is the

85 See Hinman, supra note 83 , at 347 .

86 L. Wittgenstein, supra note 1, \I 357.

87 Id. If 625 ; Hinman, supra note 83 , at $340-41$.

88 L. Wittgenstein, Philosophical Investigations $\{241$ (G. Anscoinbe trans. 1953) (emphasis in original).

89 1 E. Tylor, Primitive Culture: Researches into the Development of Mythology, Philosophy, Religion, Art, and Custom 1 (1871). See also Berkhofer, supra note 75, at 79-80 (comparing this description to later formulations of "culture"). 
holistic view that hes at the core of the traditionalist position. ${ }^{90}$ Anthropologists such as James Clifford, Michael Fischer, and George Marcus have argued that this traditional idea of culture is inconsistent with the critique of absolutes, noting that it "reflects the persistence of an ideology claiming transparency of representation and immediacy of experience." 91 The traditional view, they note, rests on the assumption that an ethnographer can observe the everyday life of the natives and provide an authoritative picture of their culture. In the words of James Clifford, a prominent inember of the group to which he refers:

[The younger anthropologists] see culture as composed of seriously contested codes and representations .... They assume that academic and hiterary genres imterpenetrate and that the writing of cultural descriptions is properly experimental and ethical. Their focus on text making and rhetoric serves to highlight the constructed, artificial nature of cultural accounts. It undermines overly transparent modes of authority, and it draws attention to the historical predicament of ethnography, the fact that it is always caught up in the invention, not the representation, of cultures. ${ }^{92}$

Clifford suggests that the traditional view of culture is inconsistent with the rejection of a "God's-Eye point of view" from which the glassy essence of culture will stand revealed.

Wittgenstein and the younger anthropologists challenge the traditionalists' view that consensus can provide a substitute foundation for traditional certamties in "the age of interpretation." Once the culture concept dissolves away, the full implications of modernisin's social theory of meaning emerge. Haskell's cozy vision of an abiding consensus lasting "more than a few generations" ${ }^{33}$ gives way to a picture

90 See Berkhofer, supra note 75; Walters, Signs of the Times: Clifford Geertz and the Historians, 47 Soc. Res. 537 (1980).

91 Clifford, Introduction: Partial Truths, in Writing Culture, supra note 24, at 2. See generally G. Marcus \& M. Fischer, Anthropology as Cultural Critique (1986) (discussing the limitations of traditional approaches to anthropology); Writing Culture, supra note 24 (collecting interdisciplinary approaches to the analysis of ethnographic writing). Another contributor to this literature is James Boon. See J. Boon, Other Tribes, Other Scribes (1982).

92 Clifford, supra note 91, at 2 (citation omitted). See also Clifford, On Ethnographic Surrealism, 23 Comp. Stud. Soc. \& Hist. 539, 550-51, 562-64 (1981) (exploring analogies between the fragmentation of the culture concept and surrealism); Cohn, History and Anthropology: The State of Play, 22 Comp. Stud. Soc. \& Hist. 198, 216-20 (1980) (anthropologists invent and modify cultures).

93 Haskell, supra note 43, at 1004. 
in which situated, social certainties-and their inevitable clashbecome a permanent part of modern society. Alasdair MacIntyre's insight that "[t]here seeins to be no rational way of securing inoral agreeinent in our culture" becoines an abiding verity from which there is no philosophical escape. ${ }^{94}$

\section{The Pragmatic Alternative: Forging a Bridge BETWEEN HOPE AND MEMORY ${ }^{95}$}

[T]he present is filled with pasts and pregnant with the future.

Wilhelm Dilthey ${ }^{96}$

A pragmatic approach abandons the search for a single viewpoint because it abandons the search for a certainty that compels agreement. In its place, pragmatism substitutes an "edifying conversation" that views societal differences as food for thought. The pragmatist's search for a workable society is a search not for universal principles but for strategies through which a population, inevitably divided by differences over a very broad range of their affairs, can seek a series of necessarily transient and provisional understandings. ${ }^{97}$

Attempting to locate promising directions within a complex society and a tradition that shapes and limits our understanding, the pragmatic approach focuses not on what could be under hypothetical conditions, but on what is. In her search for an understanding of "particular truths," the pragmatist, like the traditionalist, focuses on history; ${ }^{98}$ yet the pragmatist, unlike the traditionalist, does not examine history as the potential repository of objectivity. Instead, she

94 A. MacIntyre, After Virtue: A Study in Moral Theory 6 (1981).

95 The phrase is from Toews, supra note 25, at 900 . Prominent contemporary pragmatists include Richard Rorty and Richard Bernstem. See R. Rorty, Consequences of Pragmatism xiii-xxi, 160-75 (1982); R. Bernstein, Beyond Objectivism and Relativisın: Science, Hermeneutics, and Praxis (1983). Although my formulation is influenced by Rorty and Bernstein, it is my own; I suspect both would feel uncomfortable with it (in different ways). (They also disagree on certain issues. See R. Bernstem, supra, at 255 n.48.) In my formulation I omit the irrationalists. This is because (at least critical legal) scholars who appear to be irrationalists often appear so ouly as long as they maintain a tight focus on the critique of absolutes. Once they reach the reconstructive program, unost "irrationalists" appear as either pragmatists or neo-objectivists.

96 Quoted in Holborn, Wilhein Dilthey and the Critique of Historical Reason, 11 J. Hist. Ideas 93, 108 (1950).

97 See R. Rorty, supra note 95, at xiii-xxi, xlii-xliv.

98 See Rorty, Postmodernist Bourgeois Liberalism, 80 J. Phil. 583, 587 (1983). 
looks to history for help in guiding a pluralistic society as it negotiates agreenents that remain contested, situated, eternally unsettled.

In his book Without Foundations, Don Herzog develops a pragmatic approach to political theory. ${ }^{99}$ Herzog argues against the traditional insistence on an objectivity that coinpels agreement and sketches an alternative approach to justification.

A satisfactory justification need not put an end to all disagreements in politics; the drive to do so is drastically illiberal anyway. But our efforts at justification need not break down lielplessly at tlie first mention of bitter, prolonged disagreement. Disagreement itself is only the beginning. We want to explore why people disagree, what reasons they offer to defend their views, how compelling their reasons are. ${ }^{100}$

How can we judge if a reason is convincing without objectivity? Herzog advocates contextual justification, which he describes as justification by showing that an institution is better than the available alternatives. "A political theory of this sort, instead of fleeing the profane world of facts into the sacred realm of value, will necessarily bring in historical considerations, sometimes extensively." 101 Herzog's approach is useful because he articulates an alternative to Rawls' inore traditional atteinpt to construct a social poimt of view all can accept. ${ }^{102}$ Herzog's approach is limited, however, by its sharp focus on the canon of pohtical philosophy-Hobbes, Locke, Hune, Adanı Smith, and utilitarianism. A more interdisciplinary approach would appropriate Herzog's praguratism but would apply it to a broader description of the American tradition. ${ }^{103}$

I envision two roles for historians exploring political theory "without foundations." Historians, first, can provide a description of the social history of America's contested truths, ${ }^{104}$ one that opens up a conversation with political theorists about justice. Historians can further map out those rhetorical continuities in the American tradition that allow Americans to forge working agreements within the dense profusion of America's conflicting certanities.

99 D. Herzog, Without Foundations: Justification in Political Theory (1985).

100 Id. at 235.

tol Id. at 24-25.

102 Rawls, Kantian Constructivism, supra note 56, at 519.

103 For a different approach to pragmatic political theory, see R. Rorty, supra note 4.

104 The phrase is from Daniel T. Rodgers. D. Rodgers, supra note 62. 


\section{A. The Social History of Certainties}

For social historians to provide a more complex interpretation of America's contested truths, they must follow through the younger anthropologists' deconstruction of the culture concept. Social historians have only recently begun this project. While they have demed simce the late 1960's that American society as a whole has been characterized by consensus, most social historians have not rejected the assumption of consensus outright. Instead, they have relocated consensus from the national pohty to subgroups defined by race, class, and gender. In place of "the" American mind, the new social historians have sought out black culture, women's culture, and workingclass culture. In women's history, for example, many of the most influential works in the decade following Carroll Smith-Rosenberg's influential essay "The Female World of Love and Ritual"105 explore the outlines of women's culture. Nancy Cott links the development of nineteenth-century women's culture with modernization theory; ${ }^{106}$ Suzanne Lebsock documents the different values held by the free women of Petersburg, Virgina; ${ }^{107}$ a range of authors explore how women's culture helped forge women's new public role in nineteenthcentury reform movements such as temperance and moral reform. ${ }^{108}$

Though the early studies of women's culture often include an mitial proviso that they address only white and/or middle-class women, ${ }^{109}$ subsequent authors sometimes have ignored these cautions and have assumed a women's culture characteristic of all women. The notion of a unitary women's cnlture has come under attack both in women's history and in feminist theory. ${ }^{110}$ In an influential article in 1985,

105 Smith-Rosenburg, The Female World of Love and Ritual, reprinted in Women's America 167 (L. Kerber \& J. De Hart-Mathews 2d ed. 1987).

106 N. Cott, supra note 66.

107 S. Lebsock, The Free Women of Petersburg (1984).

108 See, e.g., B. Epstein, The Politics of Domesticity (1981); Conway, Women Reformers and American Culture, 1870-1930, reprinted in Our American Sisters 432 (J. Friedman \& W. Shade eds. 1982); Sklar, Hull House in the 1890s: A Community of Women Reformers, 10 Signs 658 (1985). Cf. K. Sklar, Catharine Beecher: A Study in American Domesticity (1973) (biography).

109 See, e.g., N. Cott, supra note 66, at 10; N. Cott, The Grounding of Modern Feminism 9 (1987).

110 See, e.g., Butler, Gender Trouble, Feminist Theory and Psychoanalytic Discourse, in Femimism/Postmodermism, supra, at 324 (feminist theory); Fraser \& Nicholson, Social Criticism Without Philosophy: An Encounter Between Feminism and Postmodernism, in Feminism/Postmodernism 19 (L. Nicholson ed. 1990) (feminist theory); Kerber, Separate 
historian Nancy Hewitt argues that the phrase "women's culture" is insensitive to the differences between working- and middle-class woinen, as well as between black and white wornen. ${ }^{111}$

Hewitt's analysis effects a reductio ad absurdum on the concept of culture parallel to that of the younger anthropologists, for her analysis leaves us with a splintering of categories: middle-class white women's culture, middle-class black women's culture, working-class native white women's culture, working-class immigrant white women's culture, working-class black woinen's culture, etc. The message that emerges is fundamental to inodernism: categories ultiinately fracture because every analysis is a situated one. As Clifford has noted, "[1]iving does not easily organize itself into a contmuous narrative."112 Yet to achieve narrative one must interpret. This does not mean that all analysis is violent, only that every analysis is inforined by a strategy for selection. But the number of strategies is potentially infinite, so any given imterpretation is at inost a "partial truth," not a final description such as that traditionally promised by the concept of culture. "Wholeness by definition becoines a thing of the past," notes Clifford, as social analysis is accorded "its full complexity of historicized dialogical relations." 113

One way to think through the imphications of Clifford's inessage is to think concretely about race, sex, and class. For example, in some contexts I feel white; im others iny race feels invisible. At times I am very conscious of beimg a woman; elsewhere, I am most conscious of being a meinber of the privileged upper-iniddle class. The point is simple: race, sex, and class are not abstract, reified "cultures," but rather influences im particular people's hives perhaps best viewed as force fields comprismg coinplex grids of significance. The importance

Spheres, Female Worlds, Woman's Place: The Rhetoric of Women's History, 75 J. Am. Hist. 9 (1988)(women's history); Scott, Deconstructing Equality-Versus-Difference: Or, the Uses of Post-Structuralist Theory for Feminism, 14 Fem. Stud. 33 (1988) (women's history and feminist theory).

111 Hewitt, Beyond the Search for Sisterhood: American Women's History in the 1980s, 10 Soc. Hist. 299 (1985).

112 Clifford, supra note 24, at 106 (noting that all ethnographies, like all texts, are partial truths). A prominent historian recently came to the same formulation (apparently independently). See Hall, Partial Truths, 14 Signs 902 (1989).

113 Clifford, supra note 24, at 114, 109; cf. Marcus, Rhetoric and the Ethnographic Genre in Anthropological Research, 21 Current Anthro. 507 (1980) (discussing the rhetoric involved in ethnographic writing and the need for an ethnographer to describe the cultural unit clearly). 
of a given category varies with time and context. Race, sex, and class will not always be the crucial categories; age, ethnicity, or sexual orientation may at times emerge as more important. ${ }^{114}$

Historians are following up these insights as they begin to deconstruct the subcultures documented by the new social history. ${ }^{115}$ Nancy Hewitt is again a leader. In a recent paper, she argues that historians should avoid arguments about whether race is more important than class, or class more important than gender, and focus instead on inventing new imagery to help explore how race, class, gender, and other categories interact. ${ }^{116}$

Other historians have begun to explore the interaction of workingclass, women's, and black cultures and the cultural mainstream in ways that have important imphications for developing a more sophisticated appreciation of America's contested truths. An example is Damiel Ernst's work in labor history. Ernst urges labor historians to view working-class culture not as a sovereigu totality but as a force field (my term, not his) through which imdividuals experience the larger cultural context. Labor historians, he argues, need to study "how fundaunental social, political and economic forces emanating from beyond the workers' reach, shaped the world in which they hived."117

These "theoretical" issues will become unavoidable as American historians shift from their recent focus on out-groups toward a new synthesis of American history. ${ }^{118}$ Thoinas Bender's is one of the inost eloquent and persistent voices urging synthesis. He has argued that historians should turn their attention to the study of "the larger, heterogeneous, and contested pohtical and cultural realm of the nation. ... The present task is to begin establishing the relationship

\footnotetext{
114 See Bordo, Feminism, Postmodernism and Gender-Skepticism, in Feminism/ Postmodernism, supra note 110 , at 139 .

115 This deconstruction is perhaps most self-conscious in women's history, which may be a result of the cross-fertilization between women's history and feminist theory.

116 N. Hewitt, From Primacy to Intersection: Recasting Questions of Gender, Race and Class (Mar. 8, 1989) (unpublished paper presented at the University of Maryland). See also A. Cameron, T. Hunter, E. Jamison \& N. Hewitt, Gender and History (Mar. 23, 1990) (Panel Discussion, Organization of American Historians Conference, Washington, D.C.) (exploring how gender, race, and class interact).

117 Ernst, Working Class Heroes and Others, 17 Rev. Am. Hist. 586, 587 (1989).

118 Bender's suggestion has proved controversial. See A Round Table: Synthesis im American History, 74 J. Am. Hist. 107 (1987).
} 
over time of the interclass, inultiethnic, and inulticultural center, what I call public culture, and the smaller, more homogeneous gemeinschaftlich groups of the periphery."119

If historians follow Bender's call, they will enter into a conversation with political theorists about justice. Bender points the way: "Only ... when exclusion and subordination are established as relations in public, can ineaning, significance, causation, and the question of justice be adequately addressed." 120 By invoking "the question of justice," Bender joins political theorists who aim to think through the tenets of a just society. Historians can inake a major contribution by abandoning the culture concept in favor of new imagery that helps capture the complex social history of America's shifting and conflicting certainties.

\section{B. The Intellectual History of Political Rhetoric}

But a vision of American society that sees fragmentation at center screen inust also account for continuities and apparent agreeinent. To focus on the example of "rights talk," if the persistence of such talk does not indicate a binding American consensus, as I have argued, what does it inean? Historians of political rhetoric, notably Daniel T. Rodgers and Raymond Williams, argue that the widespread use of keywords such as "rights," "freedom," or "the people" may serve more to veil deep disagreements than to reflect consensus. Their insightful studies show how political rhetoric has both forged provisional alliances and broken thein. In Rodgers' words:

The words we use, the words the speech writers still zing through the air, counting on something in us to nod in assent, have been inade, remade, repudiated, fought over. ... We have been too conflict-ridden a church to have a creed. The keywords, the metaphors, the selfevident truths of our politics have inattered too deeply for us to use

119 Bender, Wholes and Parts: The Need for Synthesis in American History, 73 J. Ain. Hist. 120, 132 (1986). Bender proposes to merge social and political history by redefining politics. While political historians traditionally study the formal institutions of government, Bender's definition includes " $a$ wide range of inanifestations of power ... [including the] subtle power to assign ineaning and significance to various cultural phenoinena." Bender, supra, at 126. Since such a broad definition eliminates the public/private distinction, there is a rcal possibility that Bender's "public culture" would deteriorate into an injunction to "Do Everything," thereby losing its usefulness as a new plot for American history.

120 Id. at 132. 
them in any but contested ways. ${ }^{121}$

To translate Rodgers' point into Wittgensteinian terminology, he suggests that ideological continuities indicate not a consensus of opinion but agreement on forms of life. The persistence of rights talk signals not widespread agreement on who has rights to what but a consensus that groups claiming justice will speak in terms of rights, and that their claims will be judged in part by the extent to which they can link those claims to the history of rights talk. ${ }^{122}$

This view of rights is developed by the "social history of constitutionalism"123 in a recent special edition of the Journal of American History, published under the direction of $J A H$ editor David Thelan and the prominent legal historian Hendrik Hartog. In tliat edition, Staugliton Lynd shows how late twentietli-century workers used the language of riglits to articulate a sense of entitleinent to their jobs in the face of the American steel industry's demise; ${ }^{124}$ Leon Fink examines how American workers of an earlier period struggled to "capture the constitutionalist idioin without being swallowed up by it"; ${ }^{125}$ Eric Foner explores how reconstruction blacks used rights talk to articulate their claim to full citizenship; ${ }^{126}$ and Elizabeth DuBois traces how nineteenth-century feminists used, and ultiniately outgrew, the notion of rights they inherited froin the founding fathers. ${ }^{127}$

121 D. Rodgers, supra note 62, at 16; see also R. Williams, Keywords: A Vocabulary of Culture and Society (rev. ed. 1985) (in which Williams articulates the concept of "keywords"). My basic argument is that, to the extent that Americans' use of a common vocabulary supports a consensus, it is a consensus that lacks the significance Rawls attributes to it. See supra text accoinpanying notes 53-60.

122 Rights Consciousness in American History, 74 J. Am. Hist. 795 (1987) (Part II of the Constitution and American Life).

123 Thelan, Introduction, Rights Consciousness in American History, 74 J. Am. Hist. 795, 795-97 (1987); cf. D. Rodgers, supra note 62, at 3-16 ("Vying for control of a coininon vocabulary, stealing each other's terms in hopes of investing them with radically altered meanings, political opponents have often left behind an illusion of consensus. But contemporaries knew better.").

124 Lynd, The Genesis of the Idea of a Community Right to Industrial Property in Youngstown and Pittsburgh, 1977-1987, 74 J. Am. Hist. 926 (1987).

125 Fink, Labor, Liberty and the Law: Trade Unionisin and the Problem of the American Constitutional Order, 74 J. Am. Hist. 904, 905 (1987).

126 Foner, Rights and the Constitution in Black Life during the Civil War and Reconstruction, 74 J. Am. Hist. 863 (1987).

127 DuBois, Outgrowing the Coinpact of the Fathers: Equal Rights, Woman Suffrage, and the United States Constitution, 1820-1878, 74 J. Am. Hist. 836 (1987). 
The view that ideological continuities are agreements not on opinions but on forms of life has important imphications for a pragmatic approach to pohtical philosophy. In place of the traditionalist focus on universals, pragmatist historians will focus on gaining a deeper understanding of the rhetoric that persuades Americans who are engaged in forging working agreements within a pluralistic society. A conteinporary example suggests the concrete implications of this approach to pohitical rhetoric. In the past decade the conservative revolution has dramatized the power of traditional rhetoric to build a coalition-indeed, to change the political inood within American culture. Ronald Reagan's success rested, in part, on the New Right's success in building a rhetorical universe designed to persuade by appealing to certainties that are widely held (though rarely examined). Arguably, conservatives have understood far better than their opponents the central inessage of modermism. The rhetoric of hiberals during the Reagan decade did not reflect conservatives' awareness of the need to persuade in a world without absolutes. Liberals often appeared to assume "the truth will come out" or to inoralize that "we must face hard facts," with httle sense that their "truths" are contested ones. ${ }^{128}$ Decades as the minority vision disabused conservatives of the idea that simply "telling it like it is" is the key to political success. Perhaps progressive forces eventually will get the saine inessage. The whole point, as conservatives ultimately recognized, is that Americans do not agree; the task is to construct a rhetorical uiriverse that persuades them, one resonant of "obvious" truths. The New Right's success stands as a case study in how to use resonant American rhetoric to help build an effective coalition within the dense, contradictory complexity of American truths. This approach to pohtical theory is very different from the traditionalists' continued search for core truths, but it is one that ultimately may offer greater rewards. ${ }^{129}$

128 Both Jimmy Carter and Michael Dukakis have used the "face hard facts" themeCarter constantly, Dukakis during the last presidential debate.

129 I do not mean to imply that command of rhetoric is the sole reason for the Right's suceess. The economy and other factors have no doubt played important roles as well. For recent historical discussion of the historical bases of contemporary conservatism, see Hoeveler, Ameriean Intellectual Conservatism: Is There a Usable Past?, 11 Intell. Hist. Newsl. 4 (1989) (historicist analysis of the historical rhetorics contained in contemporary conservatism); Lawson, Is There a Usable Conservatism? Some Remarks on David Hoeveler's Essay, 11 
The historical analysis of pohitical rhetoric can also provide the framework for accomphishing a key goal of pohtical theory: to forge agreements about justice. Whereas traditional political theory tends to seek out such agreements through a search for highly abstract principles, the pragmatist remains skeptical that agreement on grand principles signals agreeinent on how such principles should be apphed in specific contexts. For example, we agree that human life is sacred, but not on how to apply that principle in the context of abortion. Instead of searching for grand principles, the pragmatist concentrates on ways to create alliances among groups with divergent points of view. ${ }^{130}$ Because of the complexity of Americans' values, and the malleability of the rhetorics they inherit, any rapprocheinent of certain deeply contested issues will remain fragile. Yet by sharpening our appreciation of the areas of agreement imphicit in divergent positions, the historical analysis of pohitical rhetoric may help achieve rapprocheinent of seemingly inconsistent positions. A focus on rhetoric has the potential to open discussions grounded in inutual respect, rather than the mutual abhorrence bred by the conviction that the opposing position is inimical to the deepest verities of the American soul. ${ }^{131}$

\section{Legal History, Justice, and Certainty}

Thus far, I have treated legal history as an imtegral part of the social history of certainties and the intellectual history of pohitical rhetoric and ideology. While it is useful to view law as an integral part of these discourses, it is also useful to view it as a umque subspecies. Setting law apart from the remamder of American political culture enables us both to coinpare legal rhetoric with general pohtical dis-

Intell. Hist. Newsl. 16 (1989); Hoeveler, Conservatism Once More: A Rejoinder, 11 Intell. Hist. Newsl. 26 (1989).

130 For related approaches, see R. Rorty, supra note 48, at 319, 389-94; Rorty, Sohidarity or Objectivity? in Post-Analytic Philosophy 3 (J. Rajchman \& C. West eds. 1985); and Cornel West's analysis of pragmatic philosophy as a form of cultural criticism, C. West, The American Evasion of Philosophy 5 (1989).

One distinctive element of a pragmatic approach is its insistence that agreements are fashioned and presumably temporary, as opposed to found and presumably permanent. Compare R. Rorty, supra note 4, at xvi ("Solidarity is not discovered by reflection but created") with Rawls, Overlapping Consensus, supra note 55, at 24-25 (political theory "hopes to uncover, and to help to articulate, a shared basis for consensus").

131 The abortion debate is a fruitful arena for this kind of analysis. See S. Callahan \& D. Callahan, Abortion - Understanding Differences (1984); K. Luker, Abortion and the Politics of Motherhood (1984). 
course and to address questions of justice. It further provides a unique context for an analysis of how situated, provisional certainties generate a sense of compelledness within a form of life, despite the lack of the firm, objective limits posited by traditionalists.

If American historians seek to synthesize around the concept of pohtical culture, and legal historians explore the scope of arguments allowable within legal culture, we can ask whether legal culture "makes thinkable" a narrower band of pohtical possibility than does pohitical culture in general. If so, then we have the framework for a close analysis of Morton Horwitz's fanous "tilt" in the law, ${ }^{132}$ and, more broadly, of CLS's contention that the law functions as ideology to constrict the scope of re-visions of society. In short, we have the raw inaterials to examine the relationship between law and justice.

We can deepen our analysis by focusing on the different visions of law held by different subgroups. Hendrik Hartog, Martha Minow, and Williain Forbath have argued that we should examine not only the vision of law held by judges and other officials, but also that held by peripheral groups. They describe their "legal histories front the ground up" as follows:

These Articles .... proceed on the view that what a given group of middle and upper-middle class white men determined was the meaning of a certam set of rules could differ significantly from the meaning constructed by a group of people having different class status, race, or gender, given the effects of these differences historically on people's perspectives on the world. ${ }^{133}$

This new approach to legal history could provide the raw niaterial for a close analysis of the relationship between different segments of legal cnlture. What is the relationship between popular and official legal culture? Is the scope of the thinkable in popular legal culture narrower than the scope of the thinkable in political culture generally?

132 See Horwitz, Santa Clara Revisited: The Development of Corporate Theory, 88 W. Va. L. Rev. 173 (1985).

133 Forbath, Hartog \& Minow, Introduction: Legal Histories From Below, 1985 Wis. L. Rev. 759, 764; see also Forbath, The Ambiguities of Free Labor: Labor and the Law in the Gilded Age, 1985 Wis. L. Rev. 767 (considering judiciary's and labor movement's post-Civil War interpretations of republican conception of free labor); Hartog, Pigs and Positivism, 1985 Wis. L. Rev. 899 (exploring legal significance of American customs through competing interpretive strategies); Minow, "Forming Underneath Everything That Grows": Toward a History of Family Law, 1985 Wis. L. Rev. 819 (critiquing traditional family law history). 
Or is popular rights consciousness a way of articulating the full scope of American pohtical discourse in legal language?

We begin to see a convergence between legal histories from the ground up, pohitical philosophy, and Bender's proposed synthesis of American history. All focus on the clash of social certainties, and on which certainties predominate. In a sense we're back to Nietzsche, but with an important difference: whereas Bender and the legal historians conclude that the reigning certainty reigns because of power relationships, they do not step "beyond good and evil." They reserve the right to disagree with the convention that predominates. Bender makes this exphicit when he advocates a history that will "provoke the corrosive sorts of questions always associated with historical moments ready for social change."134

While legal histories from the ground up have potential to focus praginatic inquiries on the question of justice, they also hold promise of a more concrete inquiry into what could be called praginatic certainty: certainty in the absence of either consensus or absolutes. This project stems from Wittgenstem's analysis of rules. Rules do not, he argued, yield results in the way they traditionally have been assumed to do so, namely through semi-automatic application of the internal logic of the rule systein. Instead, understanding a rule system entails understanding the langnage game or form of life of which it is a part: rules function to explaim the conventions commonly observed in playing the game. Breaking the rules is wrong only in the sense that, if you break enough rules consistently enough, you have ceased to play the old game and have invented a new one. ${ }^{135}$

For me this describes the series of sensations one experiences when studying the history of legal doctrime. Initially the rule patterns seem foreign, the counections bizarre, and the hines drawn quite maddeningly arbitrary. Gradually, arduously, things fall into place, until at last one greets a new case without the imitial, wrenching sense of disorientation and surprise. Of course the plaintiff argned this way, you say to yourself. Of course the defendant took that tack. But another would have been inore persuasive. Look what Chancellor Kent did with the appeal: he rearranged the entire rule pattern in a way that

134 Bender, supra note 119 , at 132 .

135 L. Wittgenstein, supra note 88 , at II 198-206, 214-241. 
seems (from within the game) brilliant rather than jarring, innovative rather than bizarre. ${ }^{136}$

Losing one's sense of disorientation and surprise is only the first step, an intuitive progress in which the historian draws on a broad range of sources, constructing a context that can account for the doctrinal system's stabilities as well as its instabilities, for its openness as well as its rejection of certain options as unthinkable, sloppy, political, or, quite simply, "wrong." Learning how to function within the rule system is only the first step. The second, both harder and more interesting from a theoretical standpoint, involves identifying that coinbination of factors (jurisprudence, the doctrine itself, the characteristics of the area of social life the law addresses, national pohitical inood, regional considerations, socio-economic characteristics of the bar and the bench, etc.) which will offer a convincing explanation for the scope of the thinkable within the rules of the game as it was played.

The study of doctrine and legal rhetoric as a system of rules promises insight into that compelledness within a forin of life that traditionally has been thought of as certainty. It may help provide an alternative description of rationality that frees us from the traditionalists' terror that we will descend into irrationalism or absolute relativism if we abandon our insistence that "[o]ne simply arrives at true beliefs by obeying mechamical procedures."137 The study of doctrine is a promising darkroom for developing a new image of rationality, one that can help us explore the shape of the conversations we have chosen, and the conversations we are still free to choose.

136 This stems from my work on the history of city status in American law. See Williams, The Invention of the Municipal Corporation: A Case Study in Legal Change, 34 Am. U.L. Rev. 369 (1985); Williams, The Development of the Public/Private Distinction in American Law (Book Review), 64 Tex. L. Rev. 225 (1985); Williams, The Constitutional Vulnerability of American Local Government: The Politics of City Statns in American Law, 1986 Wis. L. Rev. 83.

137 R. Rorty, supra note 95 , at 164 . 